\title{
Study on the Legal System of Wetland Protection
}

\author{
Qingyuan Sun
}

North China Electric Power University, No.2 Beinong Road, Changping District, Beijing, China

\begin{abstract}
Wetlands are not only an important strategic resource for socio-economic development, but also a place where biological species live. With the increase of human understanding of wetlands, how to make reasonable use of wetland resources and maintain the sustainable development of wetlands has been widely concerned by the international community. And China as a country who has the largest area wetland in Asia, second largest area wetland in world, wetland protection system has gradually become an unavoidable problem. This paper mainly from the international protection of wetlands and China's domestic wetland protection point of view, and on wetland protection put forward personal views.
\end{abstract}

Keywords: System, Wetland, International protection

\section{Overview of Wetlands}

The Convention on Wetlands promulgated in 1971, a broad definition of wetlands was adopted. "The so-called wetlands presently are different kinds of natural or artificial swamplands, turf Aries or other water areas, whether permanent or temporary, containing some amount of current or immobile water, which may be fresh, salty or half salty, including water areas possessing a depth of water less than 6 meters at tide ebb.” This is merely a further interpretation of the definition of the Convention on Wetlands. Wetlands may include rivers and lakes adjacent to wetlands, coastal areas, and wetland islands or waters below the low tide depth of $6 \mathrm{~m}$. The definition is defined in 2000 and become China's official definition.

\section{An Overview of the International Law on Wetland Protection and Its Principles}

Overview of international protection of wetlands. Since the 19th century, human economy and society developed rapidly, wetland ecosystems have suffered varying degrees of damage. So in 1979 by the former Soviet Union, Canada, Australia, Britain and other 36 countries signed the "the Convention on Wetlands" in the Iranian town of Ramsar. Since then, the protection of wetlands has gradually into the international cooperation track with the world government, social groups, civil affairs involved.

First, the Convention on Wetlands gives a definition of wetlands and pointed out clearly that wetlands, with significant economic, cultural, scientific and entertainment values, and being non-renewable, have the function of regulating hydrology and protecting the living environment of animals and plants. Secondly, the Convention on Wetlands requires contracting parties to designate "appropriate wetlands" on their territory with "ecology, botany, zoology, lacustrine or hydrology", which are of international interest and are included in the "List of Wetlands of International Importance" and protection, management rational use them. Thirdly, the Convention on Wetlands requires each contracting party to establish a nature reserve in wetlands (whether or not it has been included in the Catalog) to promote the protection of wetlands and waterfowl, compensate for the loss as far as possible when the Catalog wetlands are damaged or its boundary is reduced. Fourthly, contracting parties are required to work together to coordinate and support the relevant policies and regulations for the protection of wetlands and their flora and fauna from now on and to ensure the effective implementation of wetland protection.

It is based on the requirements of the Convention on Wetlands and the situation of wetlands in various countries and the re-understanding of the importance of governments in wetlands. In addition, the Convention on Wetlands requires contracting parties to energetically organize wetland conservation education activities and mobilize the whole society to jointly carry out 
wetland protection work.

In addition to the wetland protection work carried out under the framework of the Convention on Wetlands, other international organizations have joined the ranks of international wetland protection. For example, in 1995, the World Wildlife Conservation Union (IUCN), a global non-governmental organization established by the International Wetland and Waterfowl Research Agency, the Asian Wetland Bureau and the American Wetland Organization; World Conservation Union is also actively assisting its member to explore new sustainable utilization to exploit wetlands and water resources. Recommend strengthening the management of wetlands and aquatic ecosystems in order to achieve biodiversity conservation and socio-economic common development. [1]

The basic principles of the international law in wetlands protection.

First, Principles of International Cooperation. Because some wetlands are located at the junction of two or more countries, some species on wetlands are migratory species, so if you rely solely on the power of a country, cannot achieve a good effect of protecting wetlands. Thus, the principle of international cooperation was established in Article 5 of the Convention on Wetlands. The principle of international cooperation is a basic principle of modern international law and a basic principle of international environmental law. Contracting parties should identify important transboundary wetlands and shared watersheds and attach importance to national cooperation on wetland waterfowl migration routes.

Second, the principles of rational using. Principles of rational use as the basic concept of the Wetland Convention, has a very important effect on the protection of wetlands. Principles of rational use are protecting the ecological value of wetlands on the basis of a certain extent and scope of reasonable development of wetlands. This is a good solution to the interest conflict between the wetland ecological environment protection and economic development.

China is one of the most abundant wetland biodiversity countries in the world. China also has the most kind of wetland, the largest range and the highest number of the wetland in Asia. In addition to the Wetland Convention, the tundra wetlands have almost all types of wetlands and have unique alpine wetlands. Since joining the Convention on Wetlands in 1992, the number of international important wetlands in our country has reached 49 places.

\section{Legislative Defects in Wetland Protection in China}

Lack of sound national level legislation. At present, China's legislation on the protection of wetlands at the national level only has the "wetland management regulations "which established in March 2013 promulgating by the State Forestry Administration. The clause has only 37 articles. First, it defines science for the concept of wetlands. The definition of the wetlands is using the "concept + enumeration" approach. In this way, the definition can contain relatively large flexibility possibility. [2]

Second, the rules of the compensation and punishment mechanism is not perfect, as the twenty-fourth articles, despite the compensation clause, because there is no matching loss calculation method, is difficult to implement in practice.

Wetland management mechanism is not perfect. First, In accordance with the provisions of the Environmental Protection Law, the environmental protection department shall supervise and manage the environmental protection work, and the management system stipulates that the management of wetland protection shall be supervised by the forestry department. The description of the wetland management mechanism is also jointly managed by the People's Government and the Forestry Bureau. Wetland protection should also pay attention to the protection of the object of the forest management functions, and in wetland management, the Forestry Bureau does not have the advantages of efficiency and professional advantages.

Second, sub-sector management is also contrary to the principle of comprehensive management. For example, wetland management permits for wetland use, such as water use permits, deforestation permits, etc., are issued by multiple departments, which in practice add a lot of difficulty to the overall planning of wetland protection. 
Third, China's lack of unified monitoring and evaluation system cannot timely and accurate access to wetland information is disadvantage to wetland protection.

Fourth, China's wetland protection is facing the problem of lack of funds. At present, China's wetland management funds mainly from the international wetland protection organizations and national financial allocation of funds, because a single source of funds, it is difficult to independent development.

Therefore, in the wetland management mechanism, China has a lot of room for improvement.

\section{The Way to Solve the Legislation of Wetland Protection in China}

Improve the national legislation on wetland protection. China's current national legislation on wetland protection is the 2013 effective "wetland management regulations", which to some extent to fill the gaps in China's national legislation on wetlands, marking the protection of wetlands in China into a new stage. The newly revised Environmental Protection Act implemented on January 1, 2015, also included wetlands as an independent factor for the first time in the environmental context referred to in the Act. This is also an important step forward in China's wetland legislation. Considered China's huge area in wetland, is full of challenges in Chinese wetland protection. Coupled with the early days of the founding of the people and the government did not recognize the importance of wetlands, wetlands for a lot of destructive development, which are our current wetland protection put forward higher requirements. Therefore, China should soon develop and improve the national wetland protection legislation.

First, wetland protection as a comprehensive problem, China's legislation for it is still not enough in place, which is reflected in China's comprehensive management of wetlands is not perfect, many wetland protection issues need to be invoked to separate the relevant elements of the relevant legislation.

Such as invoking the "Water Law of the People's Republic of China" to protect the water quality of wetland, the single factor as the core of the legislation has a strong purpose, such as the purpose of legislation is to protect the winter habitat of migratory birds, then the corresponding requirements for water quality, fishing and land, etc., should meet the habitat requirement as a standard. This method of legislation is more intuitionistic, there is no different requirements of different departments, leading to some elements, although in line with the law, but cannot meet the legislative situation existed.

However, the law created under this legislative principle is not necessarily the optimal solution, and its viability is also questionable. The core area of the wetland protection, the establishment of the test area and the buffer zone, in addition to considering the elements of ecological protection, also consider the issue of wetland tenure, compensation issues and wetland use restrictions. The question of compensation should also take into account the compensation capacity of the Government. In wetland legislation, we also have to pay attention to the cost and effectiveness of the system. Only by taking into account the economic factors and ecological factors, in order to make wetland protection sustainable development. Only with the assistance of the legal system can the wetland protection be regulated so that the excellent system can be sustained. Therefore, wetland protection legislation needs to coordinate the advantages and disadvantages of different areas, comprehensive, systematic and integrated wetland protection legislation design.

Second, the lack of a unified national legislation also caused the lack of integrity and systematic. This has increased the difficulty of different wetland management experience exchange, is not conducive to the development of wetland protection legislation. And for the cross-administrative areas of wetlands, because the lack of a unified national legislation, different administrative regions are also difficult to harmonize, easy to form a legal blind spot where management unable to control.

Improve the wetland management system. Firstly, clear the application of wetland management system object, so as to promote the construction of related systems. For the concept of wetlands, we should adopt the "principle + technology" legislation approach, we need to use 
macro-concept, in line with international standards, taking into account the actual situation in China, some concepts can also invoke existing laws and regulations, to reduce legal loopholes. Secondly, prefect the system of wetland's ownership. The ownership system of wetland protection should be determined by the national level legislation to establish the basic principles, according to local specific circumstances, in accordance with national legislation to develop local laws. But our current local legislation is mainly direct copy; this approach is far from meeting the special needs of the wetlands.

Taking the ecological status of Dongting Lake ${ }^{\mathrm{i}}$ wetland in China as an example, because the people's awareness of environmental protection and the government's growing emphasis on environmental protection, Dongting Lake wetland has long been into a comprehensive management period. However, since the founding of the early so far, Dongting Lake carried out several large-scale reclamation activities, the data show that the Dongting Lake wetlands due to reclamation to reduce the wetland area of up to 160,000 square kilometers. As the important ecological value of the Dongting Lake wetland has been gradually recognized by the people, the local government of the Dongting Lake Wetland has implemented the "Pushing over the embankments and returning grain fields to the lake" under the premise of a large number of international environmental organizations and government investment and government policy support. But for other wetland protection system, ecological construction land, flood control land, construction land and industrial and agricultural production land is still a problem, only to improve the wetland ownership system, implementation the principle of "who polluters who govern" , can really establish for our wetland protection Model and achieve "wetland protection management regulations" in the reward and punishment measures.[3]

In addition, improve the wetland ownership system is also reflected in the perfect local wetlands on the right to the relevant provisions of the right to apply for documents, issued and so must have a clear provision for wetlands to act in order to assist the wetland protection management departments in the protection of wetland management activities can be carried out under the protection of the law, we should give wetland protection management departments of the right to use wetlands and other related rights. Finally, we should pay attention to wetland grading in wetland protection, such as protected area wetland and non-protected area wetland, according to the characteristics of the wetland to develop more targeted provisions to regulate its protection process.

Formulate wetland ecological compensation system. The most important contradiction in the development and utilization of wetlands is the contradiction between wetland ecological protection and economic development. For wetlands within a certain limit, the rational use of ecological and economic development can achieve the goal.

China should improve the wetland ecological compensation system in three aspects, the first is the government level of wetland compensation transfer payments. In order to make the wetland conservation project sustainable development, the government should compensate the farmers who respond to the wetland protection policy and the enterprises that have been damaged. This is relatively good in the protection of the Dongting Lake wetland, but how to apply the success stories of Dongting Lake wetland protection to the protection of other wetlands in China is still a problem. Secondly, the value system of ecological compensation for wetland system should be established. The universal ecological compensation value calculation system is the foundation of the ecological compensation system. Finally, the establishment of wetland ecological compensation system should consult the experts' opinions and suggestions, in particular, should pay attention to the existing problems of wetland ecological compensation and strengthen the practicability of wetland ecological compensation system.

Promote cooperation between countries on wetland protection. First, China's wetland protection legislation is not perfect, learn from the wetland protection of more mature countries, wetland protection legislation, can promote the development of China's wetland protection legislation.

Second, wetland protection needs to be applied to a variety of disciplines. Wetland-related 
research also requires the development of basic disciplines as a prerequisite. Through the cooperation between wetlands in the country, we can make up for the shortage of some basic disciplines and improve the environmental monitoring and other aspects of wetland research

Third, some species in the wetland ecosystem will be transnational migration, and only to promote cooperation between wetlands in the country, in order to more effectively protect the wetland ecosystem.

\section{Conclusion}

With the rise of the global environmental protection wave and the development of the protection mechanism of wetland international law, more and more countries are beginning to realize the value and importance of wetlands, and actively participate in the process of wetland protection; China's wetland protection legislation is also rapid development. But because of the late start, legislation is not yet sound. We should combine the current international organizations on the protection of wetlands, reference to developed countries, wetland legislation, and the continuous development of China's wetland protection mechanism.

\section{References}

[1] Y.H.Chen. China's wetland protection legal system perfect research [D]. Northwest A \& F University, 2015.

[2] X.S.Huang and Y.Z.Huang. China's population. Resources and the environment [J]. China Population. Resources and Environment, 2005 (06).

[3] (Social Science Edition) Journal of East China University of Political Science and Law Journal of East China University of Political Science and Law Journal of East China University of Political Science and Law Journal of East China University of Political Science and Law Journal of East China University of Political Science and Law Journal of East China University of Political Science and Law, 2010(01). 